UDC: $881.111: 159.9+367$

DOI: https://doi.org/10.24195/2414-4665-2017-6-21

\author{
Liliya Morska, \\ PhD (Doctor of Pedagogical Sciences), professor, \\ head of the Department of English Philology, \\ Iryna Levchyk, \\ PhD (Candidate of Pedagogical Sciences), associate professor, \\ Department of Foreign Languages, \\ Ternopil Volodymyr Hnatiuk National Pedagogical University, \\ 2, Maksyma Kryvonosa Str., Ternopil, Ukraine
}

\title{
FORMATION OF PROFESSIONAL ENGLISH COMPETENCE IN FUTURE PSYCHOLOGISTS' SPEECH
}

The article highlights the peculiarities of teaching professional English to future psychologists to use it when dealing with conflict situations. The developed methodology is aimed at modelling the teaching process taking into consideration the content of learning, its purposes, methods and control tools. The relevance of the issue studied is caused by the absence of an integrated methodology of teaching the foundations of professional activity and foreign language communication to future psychologists concerning their role of a conflict mediator. In focus of close interconnection of linguistic and occupational activities the psychological characteristics of generation and reproduction of mediator's communication in the mediation process have been investigated, therefore the main types of mediators' communicative behaviour according to the algorithm of their professional activity have been determined. They include auditory speaking behaviour (introductory skills), dialogue and polylogue speaking behaviour (clarifying skills), informative selective speaking behaviour (alternative speaking skills), verbal motivating speaking behaviour (persuasive skills), and spontaneous regulative speaking behaviour (contractual skills). In accordance with the designed model of the formation of professional English competence in future psychologists' speech the subsequent system of exercises with accompanying methodological recommendations has been described. During the experimental trials the questioners and tests were used in experimental and control groups. The results of control test at the final stage of the experiment have shown positive dynamics of students-psychologists' English professional competence in the experimental groups according to the established criteria.

Keywords: professionally oriented English, modelling of the teaching process, psychologist-mediator, types of communicative behaviour, algorithm of professional activity, speaking skills.

\section{Introduction}

Careful attention to the issue of teaching professional English to future psychologists has been caused by the necessity to establish and develop contacts between Ukrainian and foreign experts of various production and non-production spheres of life, including mediation in conflict situations; it generally corresponds to the direction defined by the National Strategy of Ukraine in 20122021 years. This process involves providing conditions for training highly qualified specialists in various fields having a good command of a foreign language. Besides, in terms of Ukraine's accession to the world's educational space, learning English as a second language has acquired the status of a mandatory component of future specialists' professional competence.

Ukrainian citizens being in close contact with their foreign partners need mediators' help to settle professional or domestic conflicts. Therefore, these professionals must have a high level of both professional and foreign language competence. Hence, there arises the issue of teaching professional English to future psychologists, especially to those who deal with conflicts resolution. For the development and improvement of skills of professional English communication within the occupation of a psychologist the methodology of teaching English should be based on consideration of mediator's special verbal behaviour in conflict situations. Development and experimental testing of an effective system of exercises for training future specialists professional English communication is significant from both theoretical and practical points of view.

Review of relevant researches over the two past decades allows to infer that there have been published a number of works exploring and developing methods of future psychologists' professional foreign language skills formation. The experience-constructivist approach to teaching English through the content of the specialties comprised in the cycle of Psychology students' occupational training has been investigated by Tarnopolsky et al. [9]; a range of communication skills and corresponding frames has been developed by T. Astafurova [1]; a communicative strategy and tactics of speech behaviour in conflict situations have been analyzed [4]; a model of socio-cultural foreign language competence in Psychology students based on the content of training has been developed by I. Sultanova [14]; the methodology of teaching future psychologists to read English authentic occupation-related texts in frames of functional approach has been suggested by L. Repkina [12]; peculiarities of 
Russian and English disputants' and mediators' speech have been described by I. Pevneva [11].

However, the works of these and other authors are primarily aimed at improving foreign language skills of future psychologists through lexical and grammatical psychological content material that still keeps a gap between teaching foreign language and professional activities. Educational nature of the process of mastering a foreign language contradicts the theory of conceptual speech activity. It is well-known that the performance of any act requires direct connection with its verbal support that is possible only under condition of complete integration of two processes - occupational training and foreign language teaching of future professionals [8].

The absence of such an integrated methodology of teaching the foundations of professional activity and foreign language communication to future psychologists concerning such a psychologist's role as a conflict mediator explains the relevance of the research.

The purpose of the article is to describe the methodology of the formation of professional English competence in future psychologists' speech.

Therefore, the task of the article presupposes profound explanation of the lingual-didactic model of professional English language competence in speech of future psychologists-mediators and the subsequent system of exercises as far as the efficiency of the suggested methodology has been checked experimentally according to specially established criteria [6, c. 33].

\section{Research methods}

The hypothesis of the research implies that the professional English language competence in future psychologists' speech will be efficiently developed if it is based on previously acquired professional knowledge in students' native language, which is strengthened and practically applied in the following processes: gaining knowledge of professional vocabulary and formation of skills of its use in simple speech acts; the development of speaking skills: introductory ones by exploring the essence of the conflict via auditory speaking behaviour; clarifying ones by specifying information via dialogue and polylogue speaking behaviour; alternative ones by offering the best options for eliminating conflict via informative selective speaking behaviour; persuasive ones by proving the necessity for adopting a compromise solution via verbal motivating speaking behaviour; contractual ones by making mediation agreement via spontaneous regulative speaking behaviour.

The hypothesis of the study has been proved in the course of the conducted experiment at higher educational establishments in Ukraine: Ushynsky University and Ternopil Volodymyr Hnatiuk National Pedagogical University. The total number of students who have participated in the pilot study comprised 246 people, including in the main experiment involving 120 students.

The methods of analysis, generalization and systematization of psychological and pedagogical, methodological and linguistic studies and official documentation were applied in order to determine the definition of the concept "mediation in conflict situations", the advantages and drawbacks of existing teaching methods of a foreign language to future psychologists as well as psychological foundations of generation and reproduction of mediator's English speaking behaviour in the process of conflict mediation. The method of linguistic analysis of oral and written professional discourse was used in order to identify stylistic features of psychologist-mediator's speech. The method of modelling was applied to develop lingual didactic model of professional English language competence in future psychologists' speech. The methods of systematization and classification of the learning material and the methods of logical and didactic connection between pedagogical activities were used in order to devise the system of exercises. The effectiveness of the developed method was evaluated by means of summative and formative experiments. The levels of future psychologists' English language professional communication skills were assessed with the help of testing method. The method of statistic analysis of data was applied in order to check the reliability of the results of experimental studies, their quantitative and qualitative characteristics [6, p. 8].

Scientific novelty of the results implies the scientific substantiation and the presentation of the developed methodology of the formation of professional English language competence in future psychologist-mediator's speech. The lingual-didactical model of the process of forming future psychologists' professional English language competence has been described and designed based on the development of the five speaking skills, each of which provides professional-lexical, professional-stylistic and professional-speaking formation. There have been developed the criteria (linguistic-auditory, linguisticdialogue, informative-selective, verbal-motivating, spontaneously-regulatory) for evaluating the maturity level of professional English language competence in future psychologists' speech.

The practical significance of the obtained research results involves the development of educational and methodical complex, which consists of an experimental manual "Professionally oriented English language communication for psychologists (in conflict situations)" by Morska et al. [10] and "Basic Russian-English mediator phrase-book" [7].

The experimental approbation of the methodology aimed at the formation of professional English language competence in future psychologists' speech requires careful description of the preparation and implementation of the experiment, establishment of criteria to evaluate the maturity level of future psychologists' professional English communication skills, and interpretation of the experimental study data.

The conducted experiment involved the implementation of the following stages: theoretical, summative, and formative. The efficiency of the proposed method of experimental studies was checked during the experiment, which has been natural, open and horizontal-vertical (according to 
P. Hurvych). Unvarying conditions of the experiment included: the number and nominal composition of the student groups; a teacher as the experimenter; the maturity level of the participants' skills of professional English communication at the beginning of the experiment; terms of conducting the experimental study; place of study. The variable conditions included: the content and type of the exercises, the ratio of different types of study, organization of the educational process. The students were divided into experimental and control groups randomly because the primary level of students' skills was roughly the same. Duration of the experiential study in each of the examined groups lasted for 2 terms of the academic year.

The experimental study has involved students of Ternopil Volodymyr Hnatiuk National Pedagogical University and Ushynsky University. The students of EG were taught according to the developed methodology while the students of $\mathrm{CG}$ were trained according to traditional teaching methods, implemented in educational institutions of Ukraine and presented in typical English textbooks for higher education institutions approved by the Ministry of Education and Science of Ukraine.

The criteria-based approach was used to assess the levels of professional English language competence in future psychologists' speech in pre-experimental and post-experimental tests. The criteria have been derived from the criteria and evaluation indicators listed in "The Common European Framework of Reference for Languages" [4] taking into account the assessment of the maturity level of psychologist-mediators' five profession- al speaking skills: introductory, clarifying, alternative, persuasive and contractual.

Evaluation of the maturity levels of professional English language competence in future psychologists' speech has been conducted according to linguisticauditory criterion that determines the level of understanding of the conflict essence; linguistic-dialogic criterion that determines the number of units of the clarified information; informative-selective criterion that determines the amount of the proposed solutions to the problem by the mediator; verbal-motivating criterion that determines the number of persuasive techniques applied by the mediator in speech, and spontaneously-regulatory criterion that determines the level of contract compliance with the standard mediation agreement. The maturity level of each skill has been assessed taking into account the lexical mistakes made by the students.

The tasks to check knowledge, skills and abilities according to each of the denoted criteria were developed in order to examine the maturity levels of professional English competence in future psychologists' speech. For objective evaluation of the initial maturity level of professional English language competence of future psychologists the results of the pre-experimental and post-experimental tests were interpreted with help the learning coefficient according to $\mathrm{V}$. Bezpalko [2] which implied that "an assignment is considered to be completed at the satisfactory level if the coefficient is not less than $0,7(70 \%)$ ".

\section{Research results}

The results of the experimental tests are presented in the table 1 .

Table 1.

Comparative table of the average results of the pre-experimental and post-experimental tests examining the maturity levels professional English language competence in future psychologists' speech

\begin{tabular}{|l|l|l|l|}
\hline \multirow{2}{*}{ Groups } & Average learning coefficient & $\begin{array}{l}\text { Growth of the learning } \\
\text { coefficient }\end{array}$ \\
\cline { 2 - 4 } & pre-experimental learning & post-experimental learning & $47 \%$ \\
\hline experimental group & $42 \%$ & $89 \%$ & $5 \%$ \\
\hline control group & $44 \%$ & $49 \%$ & \\
\hline
\end{tabular}

It is obvious that data presented in the table 1 indicate the insufficient maturity level of professional English language competence in speech in the both groups before the experiment. Thus, the average learning coefficient in the experimental group reached $42 \%$, and in the control one $-44 \%$. After the experimental study, all the students of the experimental group have reached and exceeded the minimum level of learning coefficient $-89 \%$, while control group students have not reached the minimum level $49 \%$. Growth of the learning coefficient in the experimental group has achieved the indicator of $47 \%$, and in the control group it has shown only $5 \%$.

The reliability and credibility of the research results have been proved by Student-Fisher methods of mathematical statistics [13]. The results of the experimental studies have shown the effectiveness of the devised methodology of the formation of professional English lan- guage competence in future psychologists' speech and confirmed the hypothesis [5, p. 13-16].

\section{Discussion}

The methodology of the formation of professional English language competence in future psychologists' speech is based on the designed lingual-didactic model, subsequent system of exercises and methodological guidelines for their effective implementation.

Lingual-didactic model of the formation of professional English language competence in future psychologist-mediators' speech involves setting five goals of teaching the following occupational activities: getting acquainted with the conflict parties; learning the main points of the conflict by means of listening to the parties' stories; discussing proposals for the optimal solution to the problem; encouraging the parties to choose a constructive solution; writing a mediation agreement between the conflict parties. The achievement of the first goal by 
means of the English language requires students to have knowledge of lexical material included in the group \#1 on the topic of conflict, as well as acquire professional and stylistic communication techniques of evoking trust and common patterns of courtesy, which are the basis of introductory speaking skills that correlate with mediator's auditory-speaking behaviour. In the process of achieving the second goal students are supposed to learn lexical material from the group \#2 (+ \#1) about the grammatical means specifying information, the knowledge of professional and stylistic speaking techniques of specification and reframing of the perceived information that are the basis of clarifying speaking skills that correlate with mediator's dialogic (polylogic) speaking behaviour. The third goal can be achieved with the help of knowledge of the lexical material belonging to the group \#3 $(+\# 2,+\# 1)$ that covers the lexical and grammatical means of expression of supplementary information, stylistic speaking techniques to encourage collaboration and generate new ideas that make the basis of alternative speaking skills that correlate with mediator's informative-selective speaking behaviour. In order to achieve the fourth goal, students gain knowledge of lexical material included in the group \#4 $(+\# 3+\# 2+\# 1)$ about the lexical and grammatical means of expression of the persuasive influence on the conflict parties' behaviour, knowledge of professional stylistic and general rhetorical speaking techniques of persuasion, empathy and validation that are the basis of persuasive speaking skills that correlate with mediator's verbal-motivating speaking behaviour. Finally, the fifth goal can be achieved by students by means of learning the lexical material of the group \#5 $(+\# 4+\# 3+$ $\# 2+\# 1)$ about the lexical and grammatical means of writing standard mediation agreements, knowledge of professional and stylistic techniques of business communication and summarizing that are the basis of contractual speaking skills that correlate with mediator's spontaneous-regulatory speaking behaviour [5, p. 10-11].

The methodology of the formation of professional English language competence in future psychologistmediator's speech consists therefore of five blocks of exercises, each of which contains exercises aiming to acquire two types of knowledge (lexical and stylistic) and exercises aiming to develop subsequent speaking skills.

\section{Conclusions}

Firstly, the analysis of teaching methods of professional foreign language communication in Ukrainian and foreign pedagogy has shown the proved expediency of teaching professional communication by means of professional subjects, and therefore the selection of occupationrelated texts and active use of the gained vocabulary when discussing occupation-related topics. Instead the reserved capacity of this approach to the formation of professional English competence in future psychologists' speech still has not been reached. They are supposed to consider the psychological characteristics of generation and reproduction of mediator' communication in the mediation process and determine the main types of mediators' speech behaviour according to the algorithm of their work.

Secondly, mediation in conflict situations is a specific type of activity, which consists of the following units: getting acquainted with the conflict parties; learning the main points of the conflict by means of listening to the parties' stories; discussing proposals for the optimal solution to the problem; encouraging the parties to choose a constructive solution; writing a mediation agreement between the conflict parties.

Thirdly, according to the research outcomes, lingualdidactic model of the formation of professional English language competence in future psychologists-mediators' speech requires the development of five professional speaking skills. These parts of models are subsequent to suggested objectives of training and presuppose the formation of three components of English competence of psychologists-mediators, namely professional-lexical one, which implies relatively complete mastering of thematic lexical and grammatical material; professional-stylistic one, which demands relatively complete mastering of stylistically-speaking techniques; professional-speaking one, which is supposed to develop the efficient occupation-related speaking skills of a mediator.

Subsequently, the formation of professional English competence in future psychologists' speech requires the completion of five blocks of exercises. Lexical exercises are aimed at studying lexical material that enables future psychologists-mediators to perform their professional duties in English. Pre-speaking exercises are aimed at the development of skills to use English stylistic occupationrelated means to influence the behaviour of an interlocutor. Speaking exercises are aimed at the development of competence skills of a psychologist-mediator. The systematic activation in speech of every unit of learning material in connection with all previously studied ones is suggested in order to prevent gaps in students' knowledge of linguistic and speech material and its permanent storage, and thus - to result in fluent English speech.

Finally, the results of the final assessment during the formative stage of the experiment have shown the positive dynamics of growth of professional English skills of students-psychologists of the experimental groups according to the following criteria: 1) the quality of understanding of the conflict situation has risen to $92 \%$; 2) the quality of the collection of supplementary information - to $91 \%$; 3) the quality of text-recommendations - to $89 \%$; 4 ) the number of used speaking techniques of persuasion to $88 \% ; 5)$ the quality of mediation agreements between the conflict parties - to $84 \%$ [5, p. 16-18].

The study described in the article does not cover all aspects of the outlined issue. Prospects of the scientific research studies involve further examination of distinct features of teaching professional English to psychologists regarding the following areas of their occupation: psychological diagnostics, psychological counselling, psychological correction and psychotherapy. 


\section{ЛІТЕРАТУРА}

1. Астафурова Т. Н. Стратегии коммуникативного поведения в профессионально-значимых ситуациях межкультурного общения: Лингвистический и дидактический аспекты: дис. ... доктора пед. наук: 13.00.02/ Татьяна Николаевна Астафурова. - М.: МДЛУ, $1997-324$ с.

2. Беспалько В. П. Слагаемые педагогические технологии / В. П. Беспалько. - М. : Педагогика, 1989. -192 c.

3. Гулакова И. И. Коммуникативные стратегии и тактики речевого поведения в конфликтной ситуации общения: дис. ... канд. филол. наук: 10.02.01, 10.02.19/ Ирина Ивановна Гулакова. - Орел: ОГУ, $2004-152$ c.

4. Загальноєвропейські Рекомендації з мовної освіти : вивчення, викладання, оцінювання / наук. ред. укр. вид. д-р пед. наук, проф. С.Ю.Ніколаєва. - К. : Ленвіт, 2003. - 273 с.

5. Левчик I. Ю.Формування професійно орієнтованої англомовної компетентності у говорінні майбутніх психологів: автореф. дис. на здобуття наук. ступея канд. пед. наук: спец. 13.00.02 «Теорія та методика навчання (германські мови)»/ I. Ю. Левчик. .Одеса: ПНПУ імені К.Д.Ушинського, 2014 - 22 с.

6. Левчик I. Ю. Формування професійно орієнтованої англомовної компетентності у говорінні майбутніх психологів: дис. ... канд. пед.наук: 13.00.02/ Ірина Юріївна Левчик. - Одеса: ПНПУ імені К.Д.Ушинського, 2014 - 203 с.

7. Левчик I. Ю.Базовий російсько-англійський розмовник медіатора: [експериментальний навч. посіб. для студ. вищих навч. закл.] / І. Ю. Левчик Тернопіль: «Вектор», 2013. - 84 с.

8. Мартынова Р. Ю. Психологические особенности лингвокоммуникативного этапа процессуальной интеграции профессиональной и иноязычной речевой деятельности/ Р. Ю. Мартынова, Л. С. Добровольская // Наука і освіта. - К., 2011, - № 2. - C. $32-41$.

\section{REFERENCES}

1. Astafurova, T. N. (1997). Strategii komunikativnogo povedeniya $\mathrm{v}$ profesionalno znachimyh situatsiyakh mezhkulturnogo obshcheniya: lingvisticheskiie i didakticheskiie aspekty [Strategies of the communicative behavior in professionally significant situations of international communication: linguistic and didactic aspects]. Doctor's thesis. Moscow: Moscow State Linguistic University [in Russian].

2. Bespalko, V. P. (1989). Slagaiemye pedagogicheskie tehnologii [Summand pedagogical technologies]. Moscow: Pedagogica [in Russian].

3. Hulakova, I. I. (2004). Kommunikativnye strategii i taktiki rechevogo povedeniya $\mathrm{v}$ konfliktnoy situatsii obshcheniya [Communicative strategies and tactics of speaking behavior in conflict situation]. Candidate's thesis. Orel: Orel State University [in Russian].
9. Методика навчання англійської мови студентів-психологів: монографія

O. Б. Тарнопольський, С. П. Кожушко, Ю. В. Дегтярьова, М. Р. Кабанова, Н. В. Беспалова ; [за заг. та наук. ред. О.Б. Тарнопольського]. - Д.: Дніпропетр. університет імені Альфреда Нобеля, 2011. - 264 с.

10. Морська Л. І. Професійно орієнтоване англомовне спілкування психологів (у конфліктній ситуації): [експериментальний навч. посіб. для студ. вищих навч. закл.] / Л.І. Морська, І.Ю. Левчик. - Тернопіль: «Вектор», 2012. $-140 \mathrm{c}$.

11. Певнева И. В. Коммуникативные стратегии и тактики в конфликтных ситуациях общения обиходно-бытового и профессионального педагогического дискурсов русской и американской лингвокультур: автореф. дис. на соискание науч. ступени канд. филол. наук: спец. 10.02.19. «Теория языка»/ И. В. Певнева. Кемерово: КГУ, 2008. - 19 с.

12. Репкина Л. И. Обучение профессионально ориентированному чтению текстов психологопедагогической направленности на основе функционального подхода: автореф. дис. на соискание науч. ступени канд. пед. наук: спец. 13.00.02 «Теория и методика обучения и воспитания (по областям и уровням образования)»/ Л. И. Репкина. - М.: МГГУ им. М.А. Шолохова, 2011. - 16 с.

13. Ситаров В. А. Дидактика : учеб. пособие для студ. высш. пед. учеб. заведений ; под ред. В.А.Сластенина / В. А. Ситаров. - М. : Академия, 2002. - $368 \mathrm{c}$.

14. Султанова И. В. Формирование иноязычной социокультурной компетенции у студентовпсихологов :на материале английского языка: автореф. дис. на соискание науч. ступени канд. пед. наук: спец. 13.00.02 «Теория и методика обучения и воспитания (по областям и уровням образования)» / И. В. Султанова. - Волгоград: ПГЛУ, 2007. - 24 с.

4. Council of Europe (2003). The Common European Framework of Reference for Languages: learning, Teaching, Assessment. Strasbourg: Language Policy Unit [in English].

5. Levchyk, I. Yu. (2014). Formuvannia profesiino oriyentovanoi anhlomovnoi kompetentnosti u hovorinni maibutnikh psykholohiv [Formation of professionally oriented English competence in future psychologists' speech]. Extended abstract of candidate's thesis. Odessa: South Ukrainian National Pedagogical University named after K. D. Ushynsky [in Ukrainian].

6. Levchyk, I. Yu. (2014). Formuvannia profesiino oriientovanoi anhlomovnoi kompetentnosti u govorinni maibutnikh psykhologiv [Formation of professionally oriented English competence in future psychologists' speech]. Candidate's thesis. Odessa: South Ukrainian 
National Pedagogical University named after K. D. Ushynsky [in Ukrainian]

7. Levchyk, I. Yu. (2013). Bazovyi rosisko-anhliiskyi rozmovnyk mediatora [Basic Russian-English mediator' phrase-book]. Ternopil: «Vector» [in Ukrainian].

8. Martynova, R. Yu., Dobrovolskaya, L. S. (2011). Psihologichekiie osobennosti lingvokommunikativnogo etapa protsesualnoy interratsii professionalnoy i inoyazychnoy rechevoy deyatelnosti [Psychological peculiarities of the lingual-communicative stage of processual integration of speaking activity]. Nauka i osvita - Science and education, 2, 32-41 [in Russian].

9. Tarnopolsky, O. B., Kozhushko, S. P., Degtiarova, Yu. V., Kabanova, M. P., Bespalova, N. V. (2011). Metodyka navchannia anhliiskoi movy studentivpsykholohiv: monografiia [Methodology of teaching English to Psychology students: monograph.]. Dnipro: Alfred Nobel University [in Ukrainian].

10. Morska, L. I., Levchyk, I. Yu. (2012). Profesiino oriientovane anhlomovne spilkuvannia psykholohiv (u konfliktnii sytuatsii): [Professionally-oriented English language communication for psychologists (in conflict situations)]. Ternopil: «Vector» [in Ukrainian].

11. Pevneva, I. V. (2008). Kommunikativnyie strategii i taktiki $\mathrm{v}$ konfliktnykh situatsiyakh obshsheniya onikhodno-bytovogo i professionalnogo pedagog- icheskogo diskursov russkoy i amerikanskoy lingvokultur [Communicative strategies and tactics of communication in conflict situations of everyday and professional pedagogical discourses in Russian and American lingual cultures]. Extended abstract of candidate's thesis. Kemerovo: Kemerovo State University [in Russian].

12. Repkina, L. I. (2011). Obucheniie professionalno oriientirovanomu chteniyu tekstov psikhologopedagogicheskoy napravlennosti na osnove funktsionalnogo podkhoda [Teaching professionally oriented reading texts of psychological-pedagogic character on the basis of functional approach]. Extended abstract of candidate's thesis. Moscow: Moscow State Humanitarian University named after M.A. Sholokhov [in Russian].

13. Sitarov, V. A. (2002). Didaktika. uchebnoie posobiie dlya studentov vyshykh pedagogicheskikh zavedeniy [Didactics. manual for students of higher pedagogical institutions]. Moscow: Academia [in Russian].

14. Sultanova, I. V. (2007). Formirovaniie inoyazychnoy sotsiokulturnoy kompetentsii u studentovpsikhologov na materialie angliiskogo yazyka [Formation of the foreign language social-cultural competence of students-psychologists by means of English materials]. Extended abstract of candidate's thesis. Volgograd: Pyatigorsk State Linguistic University [in Russian].

\section{доктор педагогічних наук, професор, завідувач кафедри англійської філології, \\ Ірина Юрї̈вна Левчик, \\ кандидат педагогічних наук, дочент кафедри іноземних мов, Тернопільський національний педагогічний університет імені В. Гнатюка, вул. Максима Кривоноса, 2, м. Тернопіль, Україна}

\section{ФОРМУВАННЯ ПРОФЕСІЙНО ЗОРІЕНТОВАНОЇ АНГЛОМОВНОЇ КОМПЕТЕНТНОСТІ У ГОВОРІННІ МАЙБУТНІХ ПСИХОЛОГІВ}

У статті висвітлено особливості навчання майбутніх психологів професійно зорієнтованої англійської мови для ефективного здійснення посередницької діяльності в конфліктних ситуаціях. Розроблена авторами статті методика спрямована на моделювання процесу навчання, взявши до уваги зміст навчання, його цілі, елементи предмету дослідження, методів та засобів контролю. Актуальність проблеми обумовлена відсутністю відповідної інтегрованої методики навчання майбутніх психологів професійної діяльності та іншомовного спілкування стосовно такої сфери професійної діяльності психолога як посередника конфлікту. Психологічні особливості зародження і відтворення мовлення посередника в процесі медіації було досліджено в призмі тісного взаємозв'язку лінгвістичної і професійної діяльності, що дозволило визначити основні види комунікативної поведінки посередників відповідно до алгоритму їхньої професійної діяльності, а саме - аудитивно-мовленнєва (ознайомче мовленнєве вміння), діалогічна або полілогічна (уточнююче мовленнєве вміння), інформативно-селективна (альтернативне мовленнєве вміння), вербально-мотивуюча (переконуюче мовленнєве вміння), спонтанно-регулятивна (договірне мовленнєве вміння). Відповідно до розробленої моделі формування професійно зорієнтованої англійської компетентності в говорінні майбутніх психологів було описано систему вправ з методичними рекомендаціями. Під час експериментальної апробації було застосовано анкетування і тестування у контрольних та експериментальних групах студентів. Результати контрольного зрізу на завершальній стадії експерименту показали позитивну динаміку зростання навичок володіння професійним англомовним спілкуванням студентів-психологів 3 експериментальних груп відповідно до встановлених критеріїв.

Ключові слова: професійно зорієнтована англійська мова, моделювання процесу навчання, психологпосередник, види комунікативної поведінки, алгоритм професійної діяльності, мовленнєве вміння. 